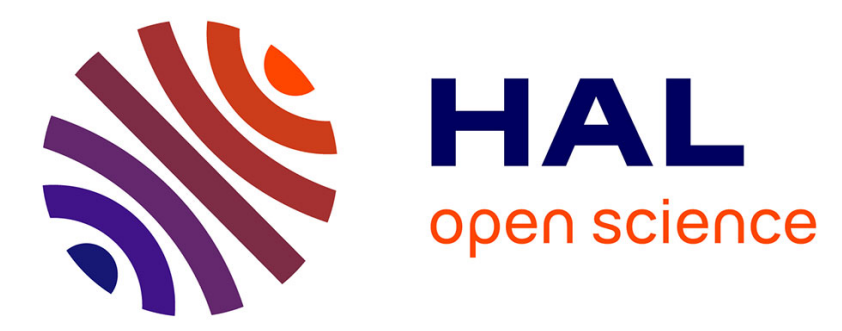

\title{
Laser-caused modification of structure and mechanical properties of silicon
}

\author{
V. Pasetchny, V. Makara, V. Sizontov, O. Rudenko, G. Vesna
}

\section{To cite this version:}

V. Pasetchny, V. Makara, V. Sizontov, O. Rudenko, G. Vesna. Laser-caused modification of structure and mechanical properties of silicon. Journal de Physique IV Proceedings, 1994, 04 (C4), pp.C4-167-

C4-169. 10.1051/jp4:1994437 . jpa-00252700

\section{HAL Id: jpa-00252700 https://hal.science/jpa-00252700}

Submitted on 1 Jan 1994

HAL is a multi-disciplinary open access archive for the deposit and dissemination of scientific research documents, whether they are published or not. The documents may come from teaching and research institutions in France or abroad, or from public or private research centers.
L'archive ouverte pluridisciplinaire HAL, est destinée au dépôt et à la diffusion de documents scientifiques de niveau recherche, publiés ou non, émanant des établissements d'enseignement et de recherche français ou étrangers, des laboratoires publics ou privés. 


\title{
Laser-caused modification of structure and mechanical properties of silicon
}

\author{
V.O. PASETCHNY, V.A. MAKARA, V.M. SIZONTOV, O.V. RUDENKO and G.V. VESNA \\ Taras Shevchenko University, Department of Physics, Volodimirska st. 64, 252017 Kiev, Ukraine
}

\begin{abstract}
There were investigated laser annealing conditions which cause relaxation of microtensions near in proximity to dislocation sources. It was dotermined that density and efficiency of such sources may be varied through oxidation of Si crystalles. Utiligation of the found conditions of thermal and laser annealing enabled the autors to set microhardness of porous $\mathrm{Si}$ and flexture of $\mathrm{Si}-\mathrm{SiO}_{2}-\mathrm{Si}$ (polycrystallic) structures .
\end{abstract}

\section{INTRODUCTION}

It is known that oxidation defects in silicon are efficient dislocation sources $[1,2]$. Thermal cycling as well as annealing of defects throungh laser radiation impulses allous to cause changes of dislocation sources state in proximity to which microtensions reached critical values. Intergrain borders also are diclocation sourses in polycrystallic silicon. In the present work the authors manager to prove that throungh annealing in the amosphere containg oxigen at temperature $1100-1200$ as well as through laser annealing of the investigated object in the air it is possible to control plastification of monocrystallic and polycrystallic silicon.

\section{EXPERIMENTAL PROCEDURE}

The oxidation defects (OD) which are the complexes of $\mathrm{SiO}_{2}$ inclusions, stacking faults and the ensembles of full and partial dislocations are widely known. Selecting the oxidation regimes that promote the growth of crystallized $\mathrm{SiO}_{2}$ inclusions we have obtained the anomaly large OD (with linear size of 10 - 20 micrometer and even more) regular geometrical shape. Oxidation defects were chosen as dislocation sources.

Porous layers on monocrystal silicon surface were obtained by means of anodic etching in electrolytes containing $H F$ in ratio $2: 1$ and $1: 1$ at currents $j=(9,0 \div 50,0) \mu \mathrm{A} / \mathrm{cm}^{2}$. The laser treatment of crystals was done by seria of impulses with the length of $4 \mathrm{~ms}, \lambda=1,06 \mathrm{~mm}$ and energy from $1 \cdot 105 \mathrm{j} / \mathrm{m}^{2}$ to $5 \cdot 105 \mathrm{j} / \mathrm{m}^{2}$.

\section{RESULTS AND DISCUSSION}

Initiatiating of dislocation generation by OD may be achieved by irradiation of Si crystal surface by pulsed laser radiation with 1,06 micrometer wave length. The threshold energy which is nessesary for dislocation generation by $O D$ (at pulse duration of $4 \mathrm{~ms}$ ) varies from $1 \bullet 105 \mathrm{j} / \mathrm{m}^{2}$ to $\mathrm{s}^{\bullet} 10^{5} \mathrm{j} / \mathrm{m}^{2}$ at sample temperature range $293 \ldots 573 \mathrm{~K}$ (Fig. 1). This energy decreases with temperature increasing (Fig.2). 


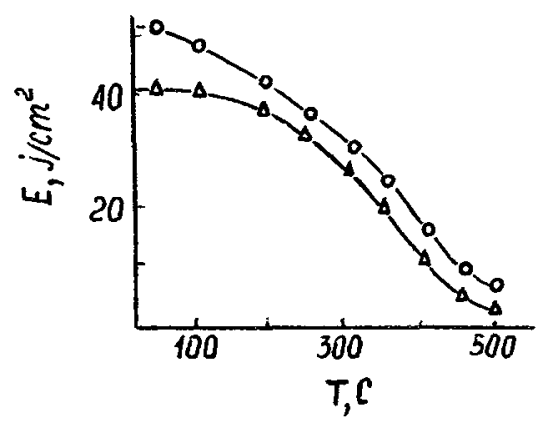

Fig.1. The temperature dependence of the threshold energy for varions dislocation sources:

- seratehes, 4 - the oxidation defects.

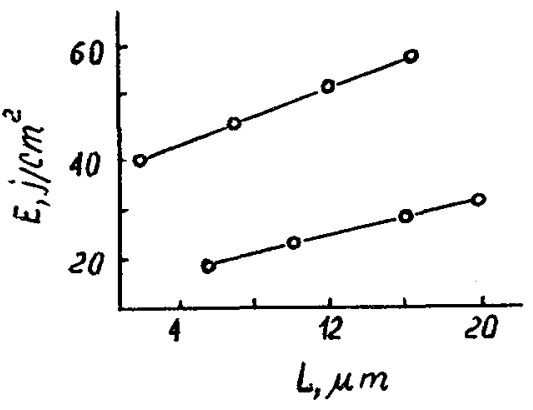

Fig.2. Variation of dislocation ensembles pathes with surface energy density of laser radiation at vartous temperatures of sample.

Unlike the thermal annealing the dislocation ensembles paths from sources is almost independent from internal stresses values, but is defined by falling pulses energy and the number of pulses. Long term irradiation of Si surface by pulsed laser with energy pulses about threshold energy is the most effective. It is possible to control both the dislocation ensembles paths and the dislocation density in the local areas of crystalsurface by the accumulation of irradiation dose.

Using of plastified annealing in oxygen ambiance made it possible to control stress relaxation process and to handle bending of three-layer $\mathrm{Si}_{\text {mono }} \cdot \mathrm{SiO}_{2}-\mathrm{Si}_{\text {poly }}$ structures. Oxidation of these structures (ratio of layer thickness was 50:1:20) in the taken regimes enables to shift the maximum of plates distribution bending by 40 ...60 micrometer (Fig 3a, 3b).

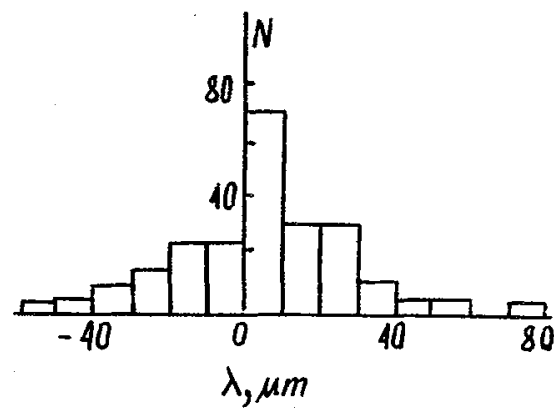

Fig.3a. The distribution of structure bending for three layeres $\mathrm{Si}_{\text {mono }}-\mathrm{SiO}_{2}-\mathrm{Si}_{\text {poly }}$ silicon structures $\quad \mathrm{h}_{\mathrm{SI}} \stackrel{\text { poly }}{=} 500 \mu \mathrm{m}$, $h_{\mathrm{SO}_{2}}=1 \mu \mathrm{m}, h_{\mathrm{SPOAYS}}=20 \mu \mathrm{m}$.

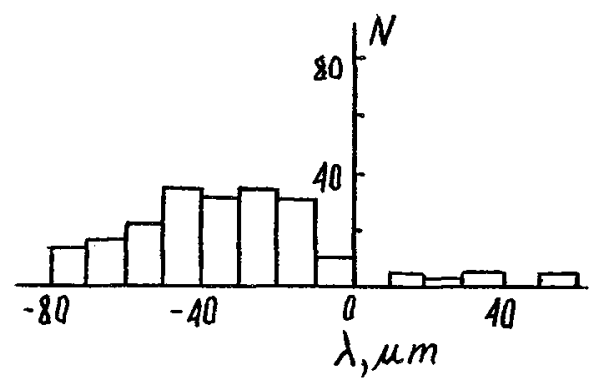

Fig.3b. The distribution shifting of structure bending after oxidlged annealing.

We started to study the influence of long-time irradiation by low power impulses on micromechanical properties of porous silicon. It was found that at doses of $150 \ldots 250$ impulses with the energy of $1,25 \cdot 10^{5} \mathrm{j} / \mathrm{m}^{2}$ (with pulse duration of $4 \mathrm{msec}$ ) the decrease of microhardness take place. The microhardness of porous silicon samples after irradiation was 20 ...50\% less (depending on the material density) than in initiation stage (Fig. 4,5 ). 


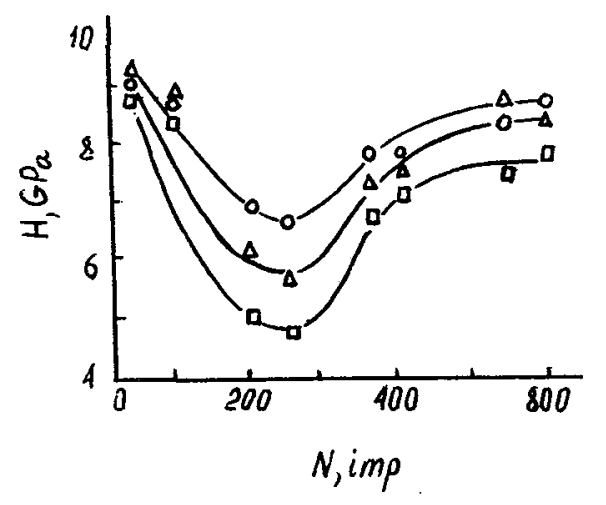

Fig. 4. The microhardness dependence of the porous silicon on the laser irradiation doze. The loading on indentor is: $1(\square)-10 \mathrm{~g}, 2(\Delta)-25 \mathrm{~g}, 3(\bullet)-50 \mathrm{~g}$.

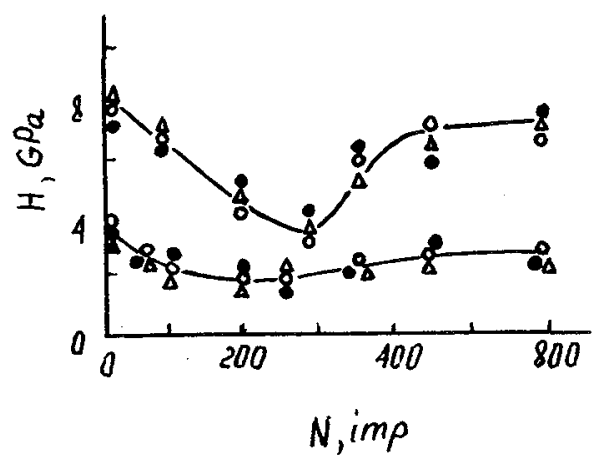

Fig.5. The microhardness dependence of the porous sillcon on the laser irradiation doze $\rho_{1}=1.77 \mathrm{~g} / \mathrm{cm}^{2}$, $\rho_{2}=0.99 \mathrm{~g} / \mathrm{cm}^{2}$. The loadin on indentor is $p=10 \mathrm{~g}$.

$$
\begin{aligned}
& (\bullet)-E_{\text {imp }}=12,5 \mathrm{~J} / \mathrm{cm}^{2} \\
& (0)-E_{i m p}=16,0 \mathrm{~J} / \mathrm{cm}^{2} \\
& (\Delta)-E_{i m p}=21,5 \mathrm{~J} / \mathrm{cm}^{2}
\end{aligned}
$$

This confirms the prospects of laser annealing application for porous silicon layer plastification.

\section{CONCLUSIONS}

1. Introduction of dislocation sources and their controlled initiatiating by thermomechanical or laser effect makes it possible to handle micro- and macroplastic properties of silicon monocrystals or lagered structures on its bases.

2. Effective dislocation sources in surface layers of Si samples can be obtained by silicon oxidation in temperature range $1050 \ldots 1200^{\circ} \mathrm{C}$. Density and power of sources can be controlled by the choice of oxidation and cooling regimes.

3. Using of plastified annealing in oxygen ambiance made it possible to control stress relaxation process and to handle bending of three-layer $\mathrm{Si}_{\mathrm{mono}^{-}} \mathrm{SiO}_{2}-\mathrm{Si}_{\text {poly }}$ stuctures.

4. Stress relaxation and plastification of silicon surface under the effect of series laser impulses makes it possible to plastify porous silicon lagers resulting in decrease of sample microhardness by $20 . .50 \%$.

\section{REFERENCES}

1. J.R. Pater, Impurity clusterine effects on dislocation generation in silicon, (Dislocation in Solids, Discussions of the Faradey Society, 1964, N38, p.201-210).

2. K.V. Ravi, Dislocation sourses in silicon, (Metallurgical Transactions, 1973, V.4, N3, p.681-689). 